\title{
Arguing The Unarguable
}

"In law a man is guilty when he violates the rights of others. In ethics he is guilty if he only thinks of doing so" - Immanuel Kant

\section{By Guru Dev Teeluckdharry (MBA - University of Leicester)}

\section{Introduction}

As to whether matters concerning ethics may be argued or not is indeed a highly debatable question that has lingered in the minds of many learned people for years and centuries. Whether it be Nicomachean Ethics of Aristotle, Shakespeare's Ethics, Kant's Ethics of Duty, Utilitarianism, Quaker Ethics, Derida Deconstruction Ethics, Virtue Ethics, Religious Ethics (which are based on scriptures such as Old Testament and Bible) or Legal Ethics, ethics unto itself is a theme that requires a very careful inspection due to its highly subjective and uncertain epistemology.

\section{Legal Ethics}

Legal Ethics is indisputably a domain that polarizes our attention to the fullest extent due to a number of explosive controversies. For instance, sanctions taken against professionals such as lawyers and attorneys on ethical grounds for malpractice are fueling interesting debates from both the fields of law and ethics worldwide. Other cases such as judicial misconduct, prosecutorial misconduct, intellectual dishonesty regarding rulings, abuse of discretion and judicial opinions tainted with fallacies are also stimulating the debate. Here, it would be wise to have a look at the analysis of learned scholars such as Sassower and Freedman. For example, Sassower (1997) in her article 'The Long Term View' raises a series of very paramount questions about the latter cases in a pertinent way. Monroe Freedman as well who is regarded as a 'prophet in his time' by Ralph J. Temple (1988) offers a very brilliant discussion in the seminal article 'Law in the $21^{\text {st }}$ century', where hestresses with vehement criticisms via reverent writings and explanations, that professionalism and ethics in the legal arena will be influenced by problematic scenarios such as 'abusive judicial conduct...,enforcement of ethics... and disciplinary processes marked by increasing judicial control' in the very near future. It is to be noted that Freedman (1991) has treated such burning issues of Legal Ethics critically that no other writer would have dared to undertake. 


\section{Ethics versus Ethics}

Another interesting issue in the Legal Ethics field, that is raising dilemmas here and there, concerns zealous advocacy exhibited by lawyers. Many lawyers take position in favour of 'zeal' which is an important element in fulfilling the duty of representing the client's interests. This very crucial factor is a fortiori enshrined in the monumental words of Lord Brougham in Queen Caroline's Case in 1820 as mentioned by Freedman (2006) in the article 'Henry Lord Brougham, Written by Himself' which are: “[A]n advocate, in the discharge of his duty, knows but one person in all the world, and that person is his client. To save that client by all means and expedients, and at all hazards and costs to other persons, and, amongst them, to himself, is his first and only duty; and in performing this duty he must not regard the alarm, the torments, the destruction which he may bring upon others. Separating the duty of a patriot from that of an advocate, he must go on reckless of the consequences, though it should be his unhappy fate to involve his country in confusion." Lord Brougham pertaining to 'zealous advocacy' further added in the same article that it is a "sacred duty that [the advocate] owes his client". In praise of zealous advocacy, Freedman (1977-1978) affirms "Let justice be done-that is, for my client let justice be done-though the heavens fall. That is the kind of advocacy that I would want to have as a client and that is the kind of representation I feel bound to give as a lawyer". Another interesting point of view about this particular notion of advocacy regarding zealous representation of a client's interest is also presented in the article 'A Critique of Philosophising About Lawyer's Ethics that a lawyer owes a "moral responsibility" to his client. In defense of zealous advocacy in 'The Evolving 'Public Interest' Dimensions of Professional Ethics for Lawyers', Brent Cotter (2007) argues that 'The Code of Professional Conduct in his own jurisdiction explicitly cites Queen Caroline's Case as a justification for the lawyer's duty of zealous advocacy' and according to him Lord Brougham's behaviour in the case raised uproar due to the fact that the latter threatened 'to take extra-judicial, extra-parliamentary measures [and] the disclosure of the King's secret marriage that would cost him his crown'. As cited in the article, this was a 'threat to the Monarch' and indeed, from one point of view, the point of view of "blackmail", in Brougham's speech is anything but professional.' It is to be noted that this particular case also raised severe ethical questions and came to be known as 'The Brougham Debate'. In addition to this, as described in 'Zealous Advocates: The Historical Foundations of The Adversarial Criminal Defence Lawyer', some theorists have interpreted this [menace of Lord Brougham] as a retraction of the ethic of partisanship, arguing that it surely sounds like a repudiation, not an endorsement'. According to Monroe Freedman as cited in the same article 'the statement [of menace] demonstrated just how far a lawyer should be prepared to go on 
behalf of the client'. If one analyses the latter veracities to the very core, one will conclude with conviction that there are two ethical sides of the same unethical coin. It would even be no exaggeration to spotlight that there is a spectacular ethical oxymoron at this juncture, since on the one hand Lord Brougham had indeed fulfilled his moral duty in line with Kant's Ethics of Duty to defend his client and there was the reverence of 'Good Will'. But then again, on the other hand he had resorted to derogatory tactics considered as being unethical from the standpoint of Virtue Ethics in order to attain that 'Good Will'. Which is which as far as this paradox is concerned?

\section{Conclusion}

To sum up, we may supplement the analysis with the golden adage of William Shakespeare (Hamlet - Act II, Scene II) which is 'There is nothing either good or bad, but thinking makes it so' to attest the applicability of ethics in our life. Besides this, one should all the time bear in mind that it is a truism that in certain circumstances not only whatever is ethical might be unlawful, but also whichever is lawful might be unethical.

\section{References}

Brent Cotter, THE EVOLVING 'PUBLIC INTEREST' DIMENSIONS OF PROFESSIONAL ETHICS FOR LAWYERS, Canterbury Law Review [Vol 13, 2007]

Elena Ruth Sassower, The Long Term View, Massachusetts School of Law, Vol. 4, No. 1, 1997, pp. $90-97$

Monroe Freedman, Law in the 21st Century, 60 Fordham L. Rev. 503 (1991).

Monroe Freedman, A Critique of Philosophising About Lawyer's Ethics, Georgetown Journal of Legal Ethics, Vol. 25, No. 89 (2012)

Monroe Freedman, Henry Lord Brougham, Written by Himself, Georgetown Journal of Legal Ethics, 2006

Monroe Freedman, Are There Public Interest Limits on Lawyers'Advocacy, Volume 02 (1977-1978)

Ralph J. Temple, MONROE FREEDMAN AND LEGAL ETHICS: A PROPHET IN HIS OWN TIME, 13 J. LEGALPROF. 233 (1988)

Tom Smith, 'Zealous Advocates: The Historical Foundations of The Adversarial Criminal Defence Lawyer', Law, Crime and History (2012) 